\title{
EVOLUSI PADA TATANAN RUANG RUMAH BADUY (STUDI KASUS : SUKU BADUY DALAM DAN BADUY LUAR)
}

\author{
Diana Susilowati ${ }^{1}$, Atiek Suprapti Budiarto ${ }^{2}$, R. Siti Rukayah ${ }^{3}$, Pancawati Dewi ${ }^{4}$ \\ 1,2,3, Program Doktor IImu Arsitektur dan Perkotaan Universitas Diponegoro Semarang \\ ${ }^{4}$ Jurusan Arsitektur Universitas Gunadarma Jakarta \\ 1'dianasusilowati@yahoo.com
}

Diterima: 28-02- 2020 Direview : 06-04-2020 Direvisi: 17-05-2020 Disetujui: 17-05-2020

\begin{abstract}
ABSTRAK. Ruang dibentuk oleh api pada saat membuat api unggun. Ruang atau tempat untuk mempertahankan api tersebut yang disebut dengan perapian (fireplace). Tujuan penelitian ini dibuat untuk memperkuat posisi studi tentang api dalam pemahaman terhadap ruang. Keterangan inilah yang menjadi latar belakang dilakukannya penelitian mengenai penggunaan perapian di rumah Baduy Dalam dan Baduy Luar, sehingga nantinya memperkaya perkembangan arsitektur Nusantara. Metode penelitian yang digunakan dalam tulisan ini adalah metode interpretive-historical research, dimana metode ini digunakan untuk mendapatkan data-data tentang perubahan atau pergeseran yang terjadi pada pola tatanan ruang dalam serta segmentasi ruang yang ada di rumah Baduy Dalam dan Baduy Luar. Pada penelitian sebelumnya banyak yang menerangkan keterkaitan antara api dan ruang. Api sebagai pencipta ruangan dapat tercipta melalui kegiatan yang terkait penggunaan api, diantaranya kegiatan untuk menghangatkan badan, memasak juga untuk penerangan. Pada rumah Baduy Dalam dan Baduy Luar, fungsi api lebih kearah pemanfaatan ruang dan perapian, hal tersebut ditunjukkan dengan adanya kegiatan yang berkaitan dengan api. Penggunaan perapian tidak mengenal perbedaan gender, artinya semua anggota keluarga dapat menggunakan parako tersebut tanpa kecuali. Jumlah parako yang ada di rumah Baduy Dalam dan Baduy Luar biasanya terkait dengan jumlah kepala keluarga di dalam rumah tersebut, dimana masing-masing parako tersebut bertanggungjawab terhadap 1 kepala keluarga yang ada di dalamnya. Evolusi ruang yang terjadi adalah adanya penambahan ruang tepas. Asal mulanya, di rumah Baduy Dalam tatanan ruang terdiri dari imah dan sasoro, lalu muncul tepas. Tepas terbentuk karena adanya penambahan kegiatan di sekitar parako.
\end{abstract}

Kata Kunci: Evolusi, Tatanan Ruang, Tungku Perapian, Baduy Dalam, Baduy Luar

ABSTRACT. Space is formed by fire when making campfires. Space or place to maintain the fire is called a fireplace. The purpose of this study was to strengthen the position of the study of fire in the understanding of space. This information is the background of research on the use of fireplaces in the Baduy Dalam and Baduy Luar house so that later it will enrich the development of the archipelago architecture. The research method used in this paper is the interpretive-historical research method. This method is used to obtain data about changes or shifts that occur in the pattern of interior space and space segmentation in the Baduy Dalam and Baduy Luar house. In previous studies, many have explained the link between fire and space. Fire as a room creator can be created through activities related to the use of fire, including activities to warm the body, cooking also for lighting. In Baduy Dalam and Baduy Luar's house, the function of fire is more towards the use of space and fireplace. This is indicated by the existence of activities related to fire. The use of a furnace does not recognize gender differences, meaning that all family members can use the parako without exception. The evolution of space that occurs is the addition of peripheral space. Originally, in Baduy Dalam house, the arrangement of space consists of imah and sasoro, then appeared tepas. It has been formed because of the addition of activities around the Parako.

Keywords: Evolution, Space Order, Fireplace, Baduy Dalam, Baduy Luar

\section{PENDAHULUAN}

Api dikenal oleh manusia sejak jaman prasejarah dan makin berkembang hingga saat ini. Salah satu usaha yang dilakukan agar api tetap bertahan adalah melalui penyediaan tempat untuk api tersebut melalui tungku perapian. Tungku perapian (hearth) adalah 
salah satu tipe tempat primitive selain altar dan makam (Unwin, 1997). Transformasi bentuk tungku perapian sendiri menurut Unwin bermula dari susunan kayu yang dibentuk melingkari api untuk membatasi tanah yang dapat terbakar, kemudian untuk mempertahankan nyala api tersebut diletakkan batu disebelah api hingga nantinya terbentuk perlindungan terhadap api seperti sebuah shelter.

Perlindungan api diatas menunjukkan bahwa terdapat perubahan pada bentuk tungku perapian. Tungku perapian yang ada nantinya akan membentuk sebuah ruang, seperti salah satu fungsi api yang disebutkan oleh Vitruvius dalam bukunya Ten Book of Architecture yaitu membentuk komunitas (Herbert Langford Warren, 2001). Dalam hubungannya dengan ruang, peran api yang penting salah satunya adalah dapat dimanfaatkan untuk memasak, menghangatkan tubuh dan untuk penerangan (Marsilio, 2014); selain itu api juga dapat dimanfaatkan sebagai sember energi (Zografos, 2019).

Teori lain juga menunjukkan ruang dapat dibentuk oleh api saat membuat api unggun. Keberadaan ruang akan sirna jika nyala api padam karena angin,hujan. Oleh sebab itu nyala api dipertahankan supaya tahan lama. maka dibentuklah dinding dan atap sehingga ketika api sudah dalam lindungan maka nyalanya akan dapat dipertahankan. Ruang atau tempat untuk mempertahankan api tersebut yang disebut dengan tungku perapian (hearth) (Crowe, 1997). Pendapat lainnya mengenai api menyebutkan bahwa api menjadi sebuah elemen penting untuk membentuk sebuah ruang (Kent, 1990). Kent juga menjelaskan bahwa organisasi ruang akan ditentukan oleh kompleksitas suatu masyarakat, terutama dalam hal segmentasi ruang. Semakin kompleks struktur masyarakat, maka akan semakin terpengaruh oleh budaya, lingkungan, penggunaan ruang, bahan-bahan lokal (terkait dengan budaya), serta arsitektur.

Pada penelitian sebelumnya, disebutkan bahwa segmentasi ruang dapat muncul akibat aktivitas disekitar perapian (Dewi \& Darjosanjoto, n.d.). Aktivitas-aktivitas yang muncul mengakibatkan terbentuknya pembagian ruangan menjadi tempat untuk memasak (dapur) dan ruangan untuk menerima tamu (pedhayohan).

Pada beberapa masyarakat masa kini yang masih kuat memegang teguh tradisi dan keyakinan, jejak perapian masih bisa dilacak, seperti pada beberapa suku yang masih bertahan di Indonesia. Dipengaruhi oleh kebudayaan dimasing-masing tempat, penggunaan perapian berbeda-beda tergantung tradisi tempat para suku tersebut berdomisili, dan biasanya diaplikasikan dalam bentuk tatanan arsitektur.

Tatanan arsitektur yang dimaksud adalah peletakan perapian yang berpengaruh terhadap aktivitas disekitar perapian tersebut, antara lain contohnya di Baduy Dalam dan Baduy Luar. Perapian dapat berfungsi sebagai pusat komunitas anggota keluarga, selain itu fungsi perapian juga untuk memasak dan menghangatkan tubuh anggota keluarga. Ada beberapa tipe rumah yang terdapat di Baduy Dalam dan Baduy Luar dimana didalamnya menunjukkan jumlah perapian di masingmasing rumah tersebut. Jumlah perapian yang bertambah ini sesuai dengan jumlah kepala keluarga yang menempati rumah tersebut, hal tersebut sesuai dengan teori (Crowe, 1997) yang menyebutkan bahwa evolusi yang terjadi pada sebuah arsitektur memiliki keterkaitan dengan evolusi yang terjadi pada api.

Oleh sebab itu, melihat penggunaan perapian yang ditunjukan diatas, maka penelitian ini dibuat untuk memperkuat posisi studi tentang api dalam pemahaman terhadap ruang. Keterangan inilah yang menjadi latar belakang dilakukannya penelitian mengenai penggunaan perapian di suku tradisional, sehingga nantinya menjadi kekayaan lokal didalam memperkaya perkembangan arsitektur Nusantara.

\section{METODE PENELITIAN}

Penelitian yang sebelumnya dilakukan berlokasi di desa Ngadisari Tengger Jawa Timur. Bahan yang dijadikan penelitian merupakan rumah tinggal penduduk lokal yang memiliki strata sosial yang berbeda. Masingmasing rumah dengan tingkat sosial yang berbeda dijadikan bahan sampel penelitian, digambarkan pola tata ruangnya sehingga diketahui letak dan jumlah tungku perapian yang dimiliki oleh masing-masing keluarga.

Bahan penelitian berupa gambar-gambar denah rumah tinggal, hasil wawancara dengan beberapa informan, seperti: sesepuh kampung serta warga lainnya yang dapat dimintai keterangan mengenai informasi perapian tersebut. Objek penelitian ini adalah rumah di Baduy Dalam, dan rumah Baduy Luar. Dari masing-masing desa yang ada di Baduy Dalam dalam hal ini desa Cibeok yang menjadi 
perwakilan, diambil masing-masing 2 sampel dari jenis rumah yang memiliki tatanan ruang yang berbeda.

Metode penelitian yang digunakan dalam tulisan ini adalah metode interpretive-historical research (Groat \& Wang, 2013). Metode ini digunakan untuk mendapatkan data mengenai perubahan atau pergeseran yang terjadi pada ruang yang memiliki tungku perapian berdasarkan temuan di penelitian sebelumnya. Melalui dokumentasi dan wawancara mendalam diharapkan dapat ditemukan data kesejarahan dari penggunaan perapian pada rumah tinggal masyarakat di Baduy.

Studi yang dilakukan berdasar fenomena yang terjadi pada saat ini, melalui peninggalan artefak masa lalu yang masih ada hingga saat ini(Muhadjir, 2011). Teori yang digunakan dipakai sebagai dasar untuk melihat sisi subyektifitas yang digunakan oleh penulis dan didasarkan kepada fenomena yang terjadi pada saat ini.

\section{PEMBAHASAN}

Salah satu peran api adalah mengubah kehidupan individual manusia menjadi kehidupan berkelompok. Hal tersebut dapat ditunjukkan pada saat api menyala. Kecenderungan orang untuk berkumpul disekitaran api dan melakukan kontak sosial dengan manusia lainnya, akan menciptakan sebuah komunitas. (Dewi, 2018)

Keterkaitan antara perapian dan komunitas berdasar pendapat Unwin dalam (Dewi, 2013) yang menyatakan bahwa ' $A$ fire not only has its own place, but also creates a place where people can occupy its sphere of light and warmth'. Contoh nyata yang dapat menunjang pendapat Unwin tersebut ada di Baduy. Baduy terbagi menjadi Baduy Dalam dan Baduy Luar merupakan suku pedalaman yang masih memegang teguh tradisi dan keyakinan kuat.

Masyarakat Baduy berada di wilayah bagian barat Pulau Jawa, pada daerah yang merupakan bagian dari pegunungan Kendeng (900 meter dari permukaan laut). Secara geografis, lokasi masyarakat Baduy ini terletak pada $6^{\circ} 27^{\prime} 27^{\prime \prime}-6^{\circ} 30^{\prime}$ Lintang Utara(LU) dan 108 ${ }^{\circ} 3^{\prime \prime}$ "-106 $^{\circ} 4^{\prime} 55^{\prime \prime}$ Bujur Timur (BT). Mereka bermukim tepat di kaki pegunungan Kendeng di desa Kanekes, Kecamatan Leuwidamar, Kabupaten Lebak, Rangkasbitung, Banten, berjarak sekitar $40 \mathrm{~km}$ dari kota
Rangkasbitung. Wilayah yang merupakan bagian dari Pegunungan Kendeng dengan ketinggian $300-600 \mathrm{~m}$ di atas permukaan laut (DPL) tersebut mempunyai topografi berbukit dan bergelombang dengan kemiringan tanah rata-rata mencapai $45 \%$, yang merupakan tanah vulkanik (di bagian utara), tanah endapan (di bagian tengah), dan tanah campuran (di bagian selatan), suhu rata-rata $20^{\circ} \mathrm{C}$.

Wilayah Baduy berbatasan dengan daerahdaerah lain; disebelah utara berbatasan dengan Desa Cibungur dan Desa Cisemeut (Kecamatan Leuwidamar); disebelah Timur berbatasan dengan Desa Sobang (Kecamatan Cipanas); disebelah Selatan berbatasan dengan Desa Cigemblong (Kecamatan Bayah); dan disebelah Barat berbatasan berbatasan dengan desa Karangnunggal (Kecamatan Bojongmanik).

Sebagai sebuah Desa, Baduy terdiri atas beberapa kampung yang terbagi menjadi dua kelompok besar, yaitu Baduy Dalam dan Baduy Luar. Kampung yang termasuk Baduy Dalam meliputi Kampung Cibeo, Cikartawarna, dan Cikeusik. Adapun kampung yang termasuk dalam kelompok Baduy Luar meliputi antara lain Gajeboh, Kaduketuk, Cisagu, Cikadu.

Secara umum, masyarakat Baduy terbagi menjadi tiga bagian, yaitu tangtu, panamping dan dangka. Tangtu dan panamping berada pada wilayah desa Baduy (Kanekes), sedangkan Dangka terdapat di luar desa Kanekes. Berdasarkan kesucian dan ketaatannya kepada adat, tangtu lebih tinggi dibanding panamping, dan panamping lebih tinggi dibandingkan dangka. Tangtu merujuk pada Baduy Dalam, sedangkan panamping dan dangka merujuk pada Baduy Luar (Permana, 2006).

Tanah tempat masyarakat tantu berdiam dianggap suci oleh orang Baduy secara keseluruhan. Sedangkan panamping berasal dari kata tamping, yang berarti kata kerja 'buang'; jadi panamping berarti 'pembuangan. Dengan kata lain, panamping merupakan tempat bagi orang tangtu yang dibuang atau dikeluarkan karena melanggar adat. Dangka menurut beberapa pendapat berarti 'rangka' atau 'kotor' sebagai tempat pembuangan warga Baduy yang melanggar adat. 


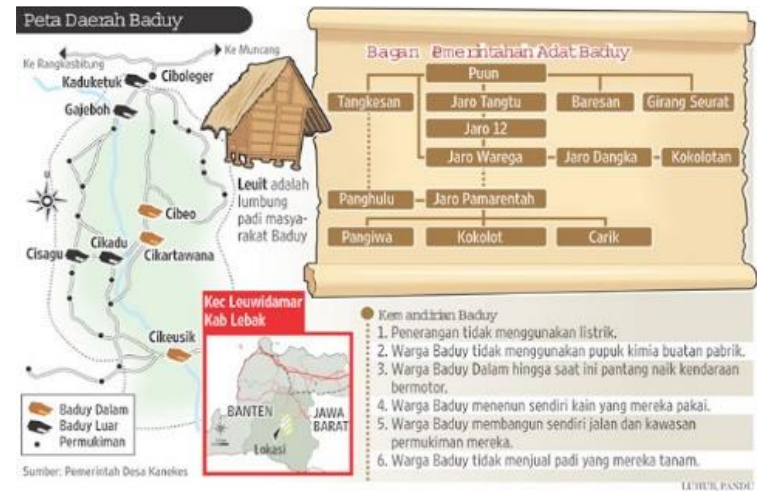

Gambar 1. Peta Daerah Baduy Luar dan Baduy Dalam

(Sumber :

https://citaariani.wordpress.com/2013/05/30/petabaduy/)

Daerah yang mereka didiami masih menjunjung tinggi aturan-aturan karuhun, antara lain tidak menggunakan aliran listrik. Penerangan dilakukan menggunakan obor dan untuk menghangatkan badan menggunakan perapian, serta fungsi lainnya dari perapian yang akan dijelaskan pada keterangan berikut ini.

Rumah Baduy secara vertikal merupakan cerminan pembagian jagat raya (Permana, 2006). Kaki atau tiang melambangkan "dunia bawah", badan atau dinding dan ruang didalamnya melambangkan "dunia tengah", dan atap melambangkan "dunia atas". Secara horisontal bagian rumah Baduy dibagi menjadi Imah (pusat atau inti rumah), Tepas (ruang tamu), Sasoro (ruang tamu, mengerjakan kerajinan, menggantung pakaian), Golodog (teras).

\section{Baduy Dalam}

Pada Suku Baduy Dalam, pola tatanan ruang memiliki lebih banyak variasi bentuk ruangan yang lebih sederhana dibanding dengan Baduy Luar, walaupun secara istilah masih sedit mirip diantara keduanya. Pada Baduy Dalam perapian memiliki fungsi yang hampir sama dengan Suku Baduy Luar, hanya saja ada sedikit perbedaan dalam bentuk letak dan jumlah perapian. Unsur api yang dapat dimanfaatkan di dalam tatanan ruang Baduy Dalam meliputi :

1. Penggunaan untuk memasak

2. Penggunaan sebagai penghangat ruangan
3. Penggunaan sebagai pembentuk komunitas, digunakan pada saat pulang dari berladang.

Pola tatanan ruang di dalam rumah Baduy Dalam dibedakan berdasarkan :

1. Rumah dengan 1 Kepala Keluarga

2. Rumah dengan 2 Kepala Keluarga

3. Rumah dengan 3 Kepala Keluarga (sudah mulai jarang keberadaannya)

Untuk rumah dengan 1 kepala kelurga memiliki susunan ruang yang terdiri dari sasoro, imah dan dibeberapa kasus tipe rumah Baduy Dalam dengan 1 kepala keluarga ada tambahan ruang tepas. Sasoro dan tepas memiliki fungsi ruang yang sama, yang membedakannya hanya susunan palupuh (lembar penyusun lantai terbuat dari bilah bambu). Jika sasoro memiliki orientasi palupuh barat-timur, sedangkan orientasi palupuh pada tepas utara-selatan.

Jumlah perapian yang dimiliki oleh Baduy Dalam berjumlah satu, dimana dapat diidentifikasi perapian yang ada terdapat dua lubang; yaitu lubang atas dan lubang samping. Lubang atas berfungsi sebagai tempat untuk memasak, sedangkan lubang samping berfungsi untuk memasukkan bahan bakar untuk perapian tersebut yang berupa kayu.
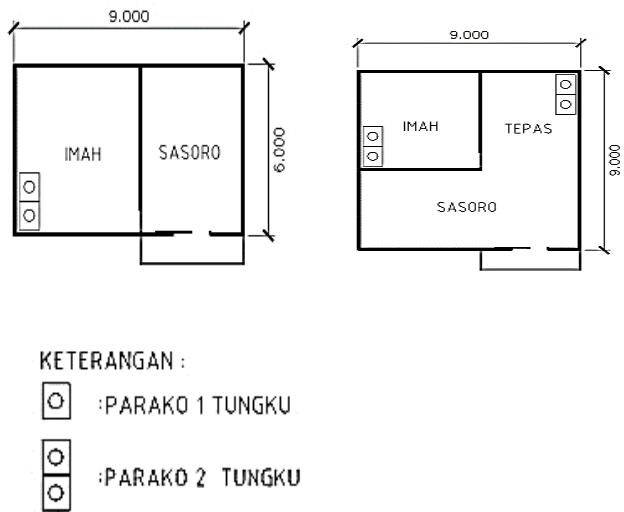

Gambar 2. Tipe Rumah Suku Baduy Dalam dengan 1 Kepala Keluarga

(Sumber : dokumentasi pribadi, 2019)

Alternatif bentuk tatanan rumah Baduy Dalam yang kedua adalah model dengan dua kepala keluarga. Model tatanan ruangan yang terdapat disini terdiri dari imah, sasoro dan tepas. Imah berfungsi sebagi inti rumah, pusat kegiatan, sasoro berfungsi untuk menerima tamu sedangkan tepas berfungsi sebagai ruang tidur tambahan. Pada rumah di Baduy Dalam, Imah berfungsi sebagai pusat kegiatan keluarga tersebut. Mereka memasak, makan, 
tidur, berkumpul bersama keluarga didalam Imah. Perapian didalamnya berfungsi ganda, sebagai tempat memasak sekaligus menghangatkan badan dan juga pusat komunitas. Penggunaan perapian tidak dibedakan berdasar gender (jenis kelamin). Anggota keluarga baik laki-laki maupun perempuan dapat menggunakan perapian tersebut.
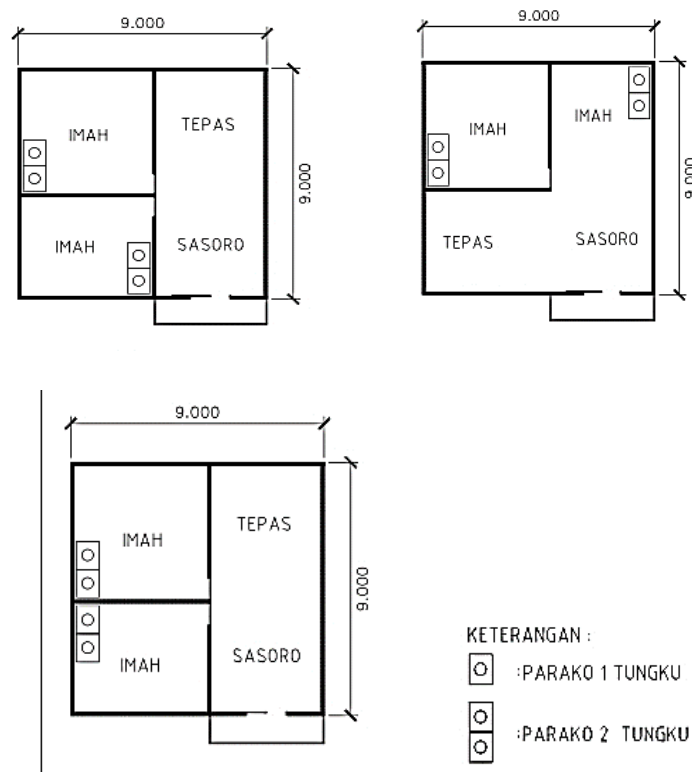

Gambar 3. Tipe Rumah Suku Baduy Dalam dengan 2 Kepala Keluarga

(Sumber : dokumentasi pribadi, 2019)

Gambar 3 menunjukkan jumlah dan variasi letak dari perapian. Susunan ruangan tetap pada prinsip yang telah disebutkan diawal, bahwa ada Golodog, Imah, Sosoro. Jumlah perapian ini biasanya dipengaruhi oleh jumlah anggota keluarga yang sudah menikah namun mengikuti orangtuanya dirumah tersebut. Jika ada anggota keluarga yang sudah menikah namun ingin tinggal bersama orangtua dirumah inti, maka keluarga baru tersebut wajib memiliki parako (tungku perapian) tersendiri.

Penggunaan parako tidak mengenal perbedaan gender, semua anggota keluarga dapat menggunakan parako sesuai dengan bagian masing-masing. Namun dibeberapa tempat, ada beberapa pembedaan bagian didalam penggunaan parako tersebut. $\mathrm{Di}$ rumah Ayah Sapri (Suku Baduy Dalam) untuk memasak Nasi dilakukan di parako rumah inti, artinya dibagian Imah keluarga tertua, sedangkan memasak lauk, air dll dapat dilakukan di parako mana saja. Tipe parako yang digunakan di Suku Baduy Dalam pun sedikit berbeda dengan Baduy Luar. Jika Baduy Luar menggunakan parako tunggal, pada Baduy Dalam model parako yang digunakan adalah dua tungku. Model parako tersebut berlaku disemua anggota keluarga di rumah tersebut.

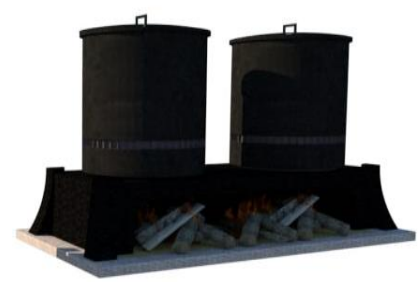

\section{Gambar 4. Model Perapian 2 tungku di Baduy Dalam}

(Sumber : dokumentasi pribadi, 2019)

Pada rumah tinggal Suku Baduy Dalam model ketiga, memiliki jumlah parako hingga 3 buah, yang menandakan bahwa dirumah tersebut terdapat tiga kepala keluarga. Ruangan yang dimiliki oleh model rumah tersebut adalah sasoro dan imah. Namun pada saat ini keberadaan rumah dengan tiga parako sudah jarang ditemui di Suku Baduy Dalam.

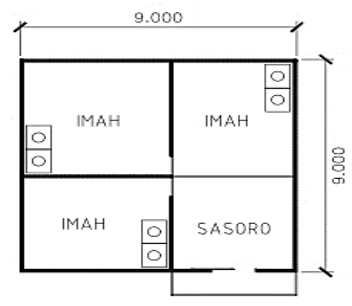

$$
\begin{aligned}
& \text { KETERANGAN : } \\
& \text { O) PARAKO } 1 \text { TUNGKU } \\
& \text { 응 PARAKO } 2 \text { TUNGKU }
\end{aligned}
$$

Gambar 5. Tipe Rumah Suku Baduy Dalam dengan 3 Kepala Keluarga

(Sumber : dokumentasi pribadi, 2019)

Di Baduy Dalam ada satu rumah yang memiliki 2 perapian, yaitu di rumah Jaro (pejabat dibawah Pu'un). Jenisnya adalah parako dan perapian, dimana parako memiliki fungsi untuk memasak, sedangkan perapian digunakan untuk menghangatkan badan ketika tamu datang berkunjung.

Perapian di suku Baduy Dalam, selain berfungsi untuk memasak, menghangatkan badan, sebagai pusat komunitas, juga berfungsi sebagai pengawet bangunan dan pengawet hasil panen mereka. Diatas perapian mereka ada tempat untuk menyimpan hasil panen yang disebut papara. 


\section{Baduy Luar}

Ada tiga ruangan dalam bangunan rumah adat ini, yaitu ruangan yang dikhususkan untuk ruang tidur kepala keluarga disebut pendeng, ruang tidur untuk anak-anak sekaligus ruang makan yang disebut tepas, dan ruang untuk menerima tamu yang disebut sosoro, serta gudang untuk penyimpanan barang yang disebut goah. Untuk teras depan ada golodog. Seluruh bangunan dibangun menghadap satu dengan yang lainnya dengan orientasi bangunan menghadap utara-selatan. Pada rumah Baduy Luar yang membedakan dengan rumah Baduy Dalam adalah jumlah pintu. Rumah suku Baduy Luar memiliki satu pintu masuk serta satu pintu keluar yang arahnya bisa dari belakang ataupun samping.

Area tepas biasanya selain berfungsi sebagai ruang makan bagi tamu, ruangan tersebut juga merupakan tempat berkumpul bagi kerabat dekat yang berkumpul dirumah tersebut. Pada saat berkumpul biasanya sekaligus menghangatkan badan dekat dengan perapian. Sedangkan parako yang memiliki fungsi sebagai tempat memasak, tempat menghangatkan badan bagi keluarga inti.
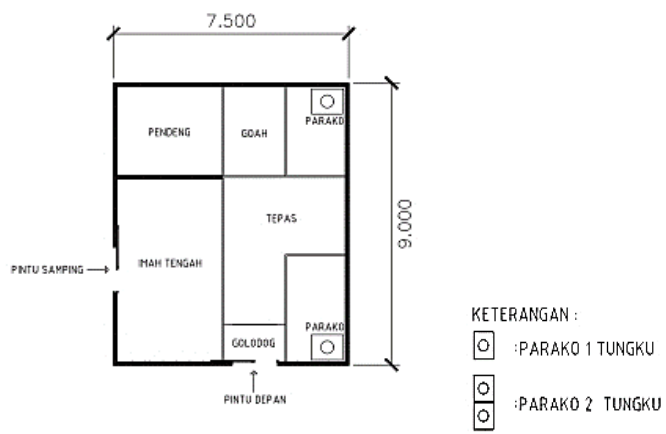

Gambar 6. Tipe 1 Rumah Suku Baduy Luar (Sumber : dokumentasi pribadi, 2019)

Pada rumah di gambar 6 menunjukkan jumlah parako yang berjumlah dua buah di rumah tersebut. Penggunaan parako dilakukan pada saat pagi hari sebelum ke ladang dan sore pada saat pulang dari ladang. Jumlah parako tersebut menunjukkan bahwa didalam rumah tersebut terdapat dua keluarga yang sudah menikah.

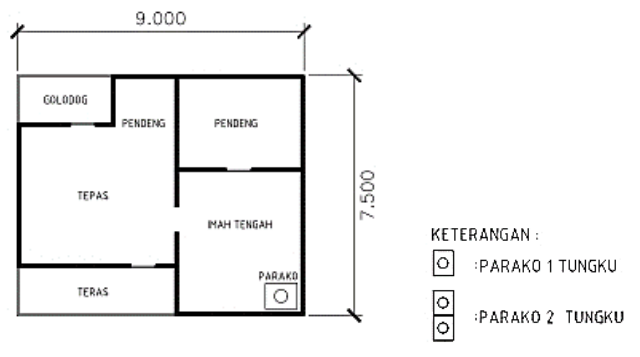

Gambar 7. Tipe 2 Rumah Suku Baduy Luar (Sumber : dokumentasi pribadi, 2019)

Pada gambar 7 diatas, parako yang ada di dalam rumah tersebut hanya satu, selain berfungsi untuk memasak parako tersebut memiliki kegunaan sebagai tempat berkumpul anggota keluarga. Ruangan yang terdapat pada model kedua rumah Suku Baduy Luar ini terdiri dari ruangan untuk tidur (pendeng), ruangan untuk berkumpul keluarga inti (imah tengah), ruangan untuk menerima tamu (tepas), teras belakang (golodog) serta teras depan.

Selain itu, fungsi perapian yang lainnya pada rumah Suku Baduy Luar adalah sebagai pengawet hasil ladang mereka. Karena sebagian besar suku Baduy memiliki mata pencaharian sebagai petani, hasil panen mereka ataupun bibit untuk musim berikutnya diletakkan diatas perapian. Hal tersebut dapat dilihat pada gambar 8 dibawah ini.

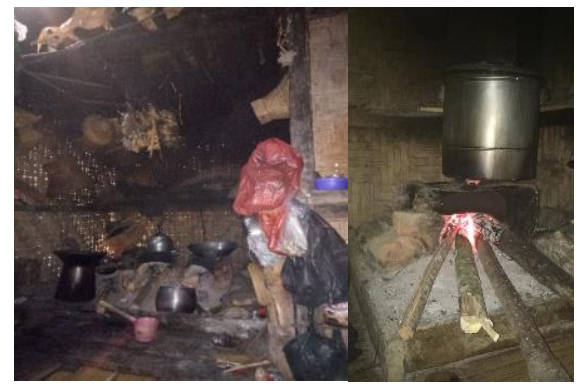

Gambar 8. Letak Hasil Panen diatas perapian dan model parako di rumah Suku Baduy Luar (Sumber : dokumentasi pribadi, 2019)

\section{KESIMPULAN}

Pada rumah di Baduy Dalam dan Baduy Luar, fungsi api lebih kearah pemanfaatan ruang dan perapian, hal tersebut ditunjukkan dengan adanya kegiatan yang berkaitan dengan api. Penggunaan perapian tidak mengenal perbedaan gender, artinya semua anggota keluarga dapat menggunakan parako tersebut tanpa kecuali. 
Ruangan awal yang terbentuk didalam rumah Baduy Dalam pada awalnya terdiri dari imah, sasoro. Namun seiring penambahan jumlah kepala keluarga, dimana setiap kepala keluarga wajib memiliki parako sendiri, maka bagi kepala keluarga baru yang tinggal bersama orang tua akan memiliki parako tersendiri. Hal tersebut mengakibatkan munculnya ruangan baru yang menjadi tempat parako tersebut yang dinamakan tepas.

Untuk ruangan yang terdapat di dalam Suku Baduy Dalam terdiri dari golodog, sosoro, imah serta dibeberapa kasus ada tambahan berupa ruang tepas untuk tempat berkumpul anggota keluarga atau sebagai tempat tidur anggota keluarga yang tidak ingin tidur di imah, serta parako yang jumlahnya tergantung dari kepala keluarga yang menempati rumah tersebut. Sedangkan di Suku Baduy Luar, pola tatanan ruangnya terdiri dari golodog, imah tengah, tepas, pendeng, goah dan parako.

Evolusi ruang yang terjadi adalah adanya penambahan ruang tepas. Ruang awal yang terjadi awalnya adalah imah dan sasoro, tepas terbentuk karena adanya penambahan kegiatan terkait munculnya parako karena jumlah kepala keluarga yang bertambah.

Jadi secara garis besar fungsi perapian yang terdapat di Baduy Dalam dan Baduy Luar ini berfungsi untuk menghangatkan tubuh, memasak, penerangan, membentuk komunitas, pengawetan bahan makanan/bibit tanaman serta sebagai simbol perapian ini berfungsi sebagai simbol penghargaan terhadap leluhur.

Perbedaan dengan penelitian sebelumnya, disebutkan jika di Tengger, akibat adanya aktivitas disekitar tungku perapian mengakibatkan terbentuknya ruangan baru serta jumlah tungku perapian. Di Baduy Dalam dan Baduy Luar, disebutkan bahwa adanya aktivitas di sekitar tungku perapian mengakibatkan ruang bertambah namun jumlah tungku perapian (parako) tetap. Jumlah parako dapat bertambah jika ada kepala keluarga yang tinggal secara bersamaan dirumah tersebut.

\section{DAFTAR PUSTAKA}

Crowe, N. (1997). Nature and The Idea of $A$ Man-Made World. United State of America: First MIT Press Paperback edition.

Dewi, P. (2013). Fire as A Creator of Space. Politics in the History of Architecture as
Cause \& Sequences, 155-163. Istanbul Turkey: Mimar Fine Arts University.

Dewi, P. (2018). Perapian Sebagai Elemen Pembentuk Identitas Arsitektur Nusantara. Seminar Ikatan Peneliti Lingkungan Binaan Indonesia (IPLBI) 2, A https://doi.org/10.32315/Sem.2.a073

Dewi, P., \& Darjosanjoto, E. T. S. B. (n.d.). The Use of Hearth in Tengger Society of East Java. International Journal of Academic Research, Vol. 3 No.(Environmental Technology, Hydrology, Forest Science), 108-114.

Groat, L. N., \& Wang, D. (2013). Architectural Research Methods. Ner Jersey: John Wiley \& Sons, Inc.

Herbert Langford Warren, A. M. (2001). Vitruvius: Ten Books on Architecture. In L. D. Morris Hicky Morgan, PH.D. (Ed.), The Classical World (Vol. 94). https://doi.org/10.2307/4352580

Kent, S. (1990). Domestic Architecture and The Use of Space. Cambridge University Press.

Marsilio. (2014). Fireplace (J. Westcott, ed.). Venezia: la Biennale di Venezia.

Muhadjir, N. (2011). Metodologi Penelitian: Paradigma Positivistik Objektif, Phenomenology Interpretative, Logika Bahasa Platonic, Chomskyist, Hegelian \& Hermeneutic, Paradigma Studi Islam, Matematik Recursion, Set Theory \& Structure Equality Modeling Dan Mixed. Yogyakarta: Rake Sarasin.

Permana, R. C. E. (2006). Tata Ruang Masyarakat Baduy. Wedatama Widya Sastra.

Unwin, S. (1997). Analysing Architecture. London: Routledge.

Zografos, S. (2019). A Psychoanalytic Approach to Conservation. In Architecture anf Fire (pp. 0-23). UCL Press. 
